\title{
HIV/AIDS Collaborative Governance and the Role of an Annual Retreat in Fostering Health Services: The Palm Beach County Experience
}

\author{
James K. Agbodzakey ${ }^{1 *} \quad$ Nicholas Bolden $^{2} \quad$ Sandra Schrouder $^{3}$ \\ 1.SERCH/Public Leadership, University of North Texas at Dallas, Dallas, TX, U.S.A. \\ 2.Department of Politics, Philosophy, and Public Administration, Columbus State University, Columbus, GA, \\ U.S.A. \\ 3.Sandra Schrouder, School of Professional and Career Education (PACE), Barry University, Miami Shores, FL, \\ U.S.A.
}

\begin{abstract}
The complex HIV/AIDS conundrum calls for innovative approaches to tackle associated challenges. The multifaceted nature of the problem and the enormous burden on various sectors of a country's economy warrant a cross-sector stakeholders' engagement for effective and sustainable solutions. This research examines the use of an annual retreat involving interviews of key stakeholders involved in health services CARE Council as an avenue for collaborative governance within a local system context in the fight against the epidemic. The results highlight how inclusive and strategic preparation can result in judicious allocation priorities for various service categories. The results also convey how relevant capacities and competencies are jointly developed through creative inputs, outputs and/or outcomes to target populations. The apparent role of facilitative leadership and the embrace of cultural humility promote mutual commitment among the stakeholders toward purposeful ends. The case represents the viability of collaborative governance as a feasible postmodern alternative to mainstream governance and service delivery to various publics, especially in this contemporary era of complexity and volatility.
\end{abstract}

Keywords: Health Services, HIV/AIDS, Annual Retreat, Target Populations, CARE Act, Collaborative Governance.

DOI: $10.7176 / \mathrm{JESD} / 10-22-08$

Publication date: November $30^{\text {th }} 2019$

\section{Introduction}

The growing complexity of problems that demand public attention also necessitate joint engagement of stakeholders from various sectors. The collective engagement of stakeholders allows for creative solutions to complex problems. Collaborative governance which usually involves stakeholders from, at least, two sectors working together to address public concerns has become an acceptable approach for tackling problems in the public sphere. Such levels of engagement whether for health, environment, law enforcement, and social services among others (Freeman 1997; Choi and Robertson 2014; Daniel, Pinel, \& Brooks 2013; Metze and Levelt 2012; Agbodzakey 2015) enable collective decision-making, the pooling of resources, and commitment that foster sustainable solutions. One such complex public problem requiring collaborative governance is the Human Immunodeficiency Virus (HIV) and Acquired Immune Deficiency Syndrome (AIDS) hereafter referred to as HIV/AIDS.

For decades, HIV/AIDS has been and is still a complex problem with devastating impacts on various segments of the population. The complexity of the HIV/AIDS problem continues despite medical advances to curb its impact. It is currently estimated that globally, about 36.7 million people are infected and living with HIV/AIDS and of this amount, an estimated 1.1 million people are living in the United States (UNAIDS, 2017; CDC, 2017). The gravity of the devastating impacts on individuals and communities call for innovative approaches to tackle the epidemic and associated challenges. In the U.S., the enactment of the Ryan White Comprehensive AIDS Resources Emergency Act (hereafter referred to as the CARE Act) in 1990 marked a political acknowledgement of the epidemic and the commitment of resources to areas that have been disproportionally impacted by the epidemic. In fact, the enactment of the CARE Act that was somewhat necessitated by fierce advocacy work, the glaring loss of lives, and a change in the national mood, demonstrated more willingness of politicians to deal with the HIV/AIDS epidemic.

As part of the implementation strategy, the CARE Act mandates establishment or designation of HIV Health Services Planning Councils to provide care and treatment in areas that are disproportionately impacted [Eligible Metropolitan Areas (EMAs)]. For instance, the CARE Act states, "to be eligible for assistance..., the chief elected official described in subsection (a) (1) shall establish or designate an HIV health services planning council..." and identifies key stakeholders to be part of the Council (CARE Act, 1990, Sec. 2602). The councils at the various EMAs are thereby tasked to make allocation priorities to various service categories for those infected and affected through collaborative engagement of cross-sector stakeholders. The efforts of the councils at the various local 
levels, collectively represent U.S. government's commitment to address the HIV/AIDS conundrum within its borders and territories even as the country is equally involved in helping address the epidemic at the global level.

Collaborative governance has thus become a commonly utilized approach by health services planning councils in the U.S. as part of the implementation of the CARE Act to provide care and treatment to target populations. Collaborative governance thereby brings together stakeholders who are mostly service providers, non-elected community leaders, and HIV/AIDS infected and affected individuals as council members to effectuate the intents and purpose of the CARE Act. Currently, the twenty-four (24) EMAs in the U.S. and its territories utilize collaborative governance to promote care and treatment of target populations.

The council in each EMA utilizes leadership and institutional design mechanisms that help fulfil its purpose. Usually, such arrangements include various committees, workshops, retreats, and other training programs to foster effective performance. For instance, workshops and other training programs are geared toward building council members' capacity in various areas on a regular basis. A retreat is usually a whole-day annual gathering of council members and other relevant stakeholders. This has become an essential forum to engage various stakeholders to promote the work of the councils. This research will focus on one of such councils, Palm Beach HIV CARE Council (hereafter referred to as CARE Council), particularly, its use of an annual retreat as an avenue to foster collaborative governance. The CARE Council has consistently utilized retreats since the early 1990s to assemble various stakeholders to discuss various themes and issues pertinent to the overall collaborative governance efforts, more so than some of the other councils, and is duly recognized for its creative approach to the annual retreat (Agbodzakey, 2015). As an avenue for collaborative governance, the annual retreat is important to the CARE Council's efforts to realize legislative intents as it relates to care and treatment of target populations.

To achieve the objectives of the study, the paper will be guided by this research question: How does the Palm Beach County's HIV CARE Council annual retreat enables HIV/AIDS collaborative governance? The research question seeks to explore how Palm Beach County's HIV CARE Council's annual retreat enables HIV/AIDS collaborative governance. The paper will highlight how the retreat enables collaborative governance of the CARE Council by relying on data garnered through observations, interviews, and review of documents. The analysis and discussion of the evidence will help draw conclusions and implications for collaborative governance in a local system context as part of efforts to collectively address the HIV/AIDS problem. The remaining sections of the paper are organized into six (6) segments. These include conceptualizing collaborative governance, excerpts on the CARE Council and the annual retreat, methodology, analysis and discussion, impact, conclusion and implication.

\section{Conceptualizing Collaborative Governance}

Collaborative governance as an emergent approach to collective problem solving has become an acceptable governing arrangement in the public sector at various levels. The opportunity that collaborative governance provides to engage stakeholders from public, private and nonprofit/civic sectors to collectively work together to address a common problem makes it very appealing (Emerson \& Nabatchi, 2015; Gray, 1989). For instance, the use of collaborative governance by HIV Health Services Planning Councils in Eligible Metropolitan Areas (EMAs) in the U.S. is a viable strategy for care and treatment of target populations (Agbodzakey, 2017). The viability of collaborative governance as a framework for collective problem solving thereby demands some conceptual explication to help relate to its core elements from theory, policy and practical perspectives. Many scholars explain the concept of collaborative governance in ways to promote knowledge and understanding of what it is and how it works. The next segment of the paper highlights the various conceptual explanations of collaborative governance; its essence, benefits and challenges.

Research by Barbara Gray (1989) serves as a seminal work on collaborative governance. The extent to which she influenced scholarship on collaborative governance is evidenced by the numerous references to her work by other scholars. According to Gray (1989), collaborative governance "is a process through which parties who see different aspects of a problem can constructively explore their differences and search for solutions that go beyond their own limited vision of what is possible" (p.5). Gray's conceptualization highlights the intentional engagement of stakeholders across various sectors to fulfil a common purpose which in this case is geared toward finding workable solutions to a problem that bedevil multiple stakeholders and to some extent society at large. The nature of the problem and the urgency for collective action by all affected and/or caring parties render sectional interests secondary as finding creative solutions to the problem. Furthermore, Gray's conceptual explanation reveals how the process of engagement by the various stakeholders in collaborative governance can set the stage for constructive deliberations that foster effective output and/or outcomes for the greater good. The perspective of Bryson, Crosby, and Stone (2006) on collaborative governance is very related to that of Gray (1989) and further underscores the collective stakeholder engagements in collaborative arrangements.

In their publication on collaborative governance which is otherwise termed cross-sector collaboration, Bryson et al. (2006) define the concept "as the linking or sharing of information, resources, activities, and capabilities by organizations in two or more sectors to achieve jointly an outcome that could not be achieved by organizations in 
one sector separately" (p. 44). This definition points to the obvious realization of the advantages of joint efforts of stakeholders from various sectors in finding effective solutions to a common problem. By pooling resources and capabilities these cross-sector stakeholders jointly create an opportunity for workable and lasting solutions that maximizes benefits to entities and society as a whole. Such level of cross-sector collaboration when appropriately designed has the likelihood to create sustainable solutions to various problems/challenges. Other scholars such as Thomson and Perry (2006), Zurba (2014), Emerson, Nabatchi \& Balogh (2012), Ansell and Gash (2008), Huxham and Vangen (2005), Ring and Van de Ven (1994), Johnston, Hicks, Nan, \& Auer (2011), Healy (1997), Beierle (2000), Rene, \& Tharsi (2004), Provan and Kenis (2008), and Sirianni (2009) share their perspectives on collaborative governance in relation to finding solutions to common and complex problems.

For Emerson et al. (2012), collaborative governance accentuate constructive engagement of actors/players from various public agencies, civic, nonprofit and private entities with established framework to collectively and responsively fulfil a public purpose. Thus, the joint efforts of cross-sector stakeholders in collaborative governance enable the addressing of a public concern which otherwise could remain unresolved if the stakeholders elect to act alone. The shared responsibility on the part of the stakeholders from cross sectors is guided by a shared understanding of the gravity of a public situation or problem and the need to act collectively create synergy for success. In fact, the exposition by Emerson et al. (2012) of collaborative governance reflects the perspective of Ansell and Gash's (2008) work which highlights multi-stakeholder engagements for decision making and/or implementation. This approach sees communication, shared understanding, commitment, consensus, leadership, and design mechanisms as essential variables that enable outputs and/or outcomes that promote problem solving for societal benefits. The stakeholders in this case are united by a common resolve to collectively address a problem whether mandated or not, despite sectional differences that they may have prior to working together or even during the course of their collective efforts.

Relatedly, Agbodzakey (2017) explication of collaborative governance as a joint undertaking by cross-sector stakeholders in making and/or implementing decisions as part of efforts to address a complex problem, further points to how a glaring challenge unites stakeholders for collective action. Specifically, the reference to HIV/AIDS collaborative governance experience of Health Services Planning Councils convey understanding of how representation and participation of relevant stakeholders in an inclusive process enable allocation priorities for care and treatment of those infected and affected by the epidemic. While the Councils' experience is within the context of mandated collaboration, the process of engagement, critical variables, and attendant outputs bear semblance to collaborative governance in dealing with any other complex problem regardless of the context.

The various conceptual explication of collaborative governance as referenced above provide an insight into how complex problems bring together stakeholders from various sectors to work assiduously to address the problem. By coming together and by establishing mechanisms for engagement, collaborative governance promotes creative and sustainable solutions with a high probability that the stakeholders will own the likely outcomes of their joint efforts. Furthermore, the conceptual expositions reveal that while the stakeholders may have obvious divergent interests, differences, and persuasions, the willingness to act collectively to address a complex problem for the most part helps dissuade unnecessary antagonism that could derail joint efforts. In fact, scholars identify likely benefits and challenges of collaborative governance which helps to highlight the realities of multistakeholder engagements for collective problem solving.

The notable benefits of collaborative governance as enumerated by scholars include collective resolve and responsibility to tackle common challenges, creative and sustainable solutions to problems, achieve economies of scale, collective resource pool to promote effectiveness, jointly structured design protocols of engagement, regular joint capacity development efforts for collective action, responsive representation and participation of relevant community and organizational stakeholders, promotion of deliberative decision making, communication, shared understanding, consensus, and legitimacy among stakeholders, and joint ownership of outputs and/or outcomes for the common good (Ansell \& Gash, 2008; Emerson et al., 2012; Bryson et al., 2015; Scott \& Thomas, 2017; Sabatier et al., 2005; Choi \& Robertson 2014; Sirianni 2009; Agbodzakey, 2012; Susskind \& Cruikshank, 1987; McGuire, 2006; Donahue \& Zeckhauser, 2011; Bel \& Warner, 2008 among others). On the other hand, observations regarding notable challenges of collaborative governance include the following: power differentiation and utilization, time and other resource constraints, turf battles, intentional holdout by some stakeholders, uncertain outcomes, occasional conflicts and ambiguity, delayed decisions, and succession challenges (Memon \& Kirk 2010; Hageman \& Bogue 1998; Scott \& Thomas, 2017; Agbodzakey, 2015; Metze \& Levelt 2012; Sabatier et al., 2005; Margerum, 2011; Emerson et al. 2012; Booher, 2004; Berardo, Heikkila, \& Gerlak 2014; Vangen \& Huxham 2012).

The enumerated benefits and challenges above point to the realities of collaborative governance in addressing complex societal problems. Nonetheless, the opportunity to bring various stakeholders from different sectors to jointly make decisions and/or implement decisions, make collaborative governance more appealing compared to adversarial management as it offers better prospects for viable solutions (Freeman, 1997; Ansell \& Gash, 2008; Gray, 1989; McGuire, 2006; Bingham and O'Leary, 2008; Healey, 1997). The next few paragraphs will highlight 
related and interchangeable terms associated with collaborative governance, the concept of governance and its connectedness to collaborative governance and how networks, cooperation, and coordination are related but different from collaborative governance.

As an emergent viable approach, collaborative governance is now commonly used at the local, state, national and international levels to tackle complex issues or concerns. Similarly, scholarly work on collaborative governance is on the ascendancy. While there is a general understanding of collaborative governance as a multistakeholder engagement across sectors for collective problem solving, scholars in their respective capacities sometimes frame the concept differently. Terms such as collaborative management, interagency coordination, participatory management, public-private partnerships, deliberative democracy, deliberative governance, participatory governance, interactive policy making, stakeholder governance, collaborative democracy, collaborative innovation, and network governance are used to connote collaborative governance (Gray, 1989; Ansell \& Gash, 2008; Anonymous, 2006; Sørensen \& Torfing, 2011; McGuire, 2006; Bryson et al., 2006; 2015; Sirianni, 2009; Sørensen \& Torfing, 2011; Provan \& Kenis, 2008; Agbodzakey, 2012). This study uses the term collaborative governance to indicate joint efforts of stakeholders across sectors to help address the complex HIV/AIDS problem with a particular focus on the experience of HIV CARE Council in Palm Beach County.

As a concept, collaborative governance has governance as a key component and scholars such as Ansell and Gash (2008); Scott and Thomas (2017) explain the nexus and variation between both terms. Governance in this context pertains to the exercise of power, authority, laws, rules, practices as it relates to delivery of public goods and services and/or conduct of public affairs in general, in either democratic or non-democratic context (Michalski, Miller \& Stevens, 2001; Fukuyama, 2013; Lynn, Heinrich \& Hill, 2000). Collaborative governance is a unique arrangement by stakeholders across sectors to address a specific complex problem, with the hope of finding sustainable solutions (Gray, 1989; Ansell \& Gash, 2008; Emerson et al., 2012). Whether mandated or not, collaborative governance promotes joint actions of various stakeholders from different spheres unlike governance which remains in the domain of the political sphere and can be exercised without direct participation of stakeholders from other sectors.

One other issue relative to collaborative governance that is worth pointing out is its relatedness and variation to concepts such as networks, cooperation, and coordination. Networks which could require multi-stakeholder engagement does not need to have a complex problem, regular face-to-face interactions, and broad participation like collaborative governance (Agbodzakey, 2012; Freeman, 1997; McGuire, 2006). Similarly, cooperation that involves different stakeholders working toward purposeful ends, and coordination which requires established protocols of engagement for joint efforts are less intense and less inclusive when compared with collaborative governance (Margerum, 2011; Bertelli \& Smith, 2010). In essence, collaborative governance promotes cooperation and coordination among stakeholders in the performance of various joint endeavours (Scott \& Thomas, 2017; Gerlak, Lubell, \& Heikkila, 2012; Karkkainen, 2002).

In the case of the Palm Beach County's HIV CARE Council for care and treatment of HIV/AIDS infected and affected persons, collaborative governance has been used for decades. The joint efforts of target populations, service providers, and non-elected community leaders with support from county, state and federal governments enabled allocation of resources for various service categories as part of the implementation of the CARE Act. The use of annual retreats as a point of convergence, deliberation, education, and strategic planning complement the Council's yearlong multi-stakeholder engagements to enable various category of services to target populations. While studies have been done on collaborative governance in various settings, the use of retreat as an avenue for collaboration and the attendant contributions has not been a focus in the scholarly literature. This study will thereby highlight the case of CARE Council's use of an annual retreat as a component of collaborative governance and will draw some implications for policy, research, and practice.

\section{Retreat as an Avenue for Collaborative Governance}

The Palm Beach County's HIV CARE Council (hereafter referred to as the CARE Council) is the health services collaborative governance entity dedicated to care and treatment of HIV/AIDS infected and affected persons in the county. The CARE Council is one of twenty-four (24) health services councils in the U.S. with a mandate to provide category of services for the target populations. Thus, as an Eligible Metropolitan Areas (EMA), the county established the CARE Council in the early 1990s to make decisions and allocate priorities as part of the implementation of the Ryan White Comprehensive AIDS Resources Emergency Care Act (CARE Act, 1990). Eligible Metropolitan Areas (EMAs) are areas disproportionately impacted by HIV/AIDS and are eligible for federal funds to provide care and treatment to those in need of service (CARE Act, 1990).

As part of the use of collaborative governance for collective problem solving, the CARE Council has various committees that enable the performance of its various roles and responsibilities. These committees are executive committee, planning committee, priorities and allocation committee, membership committee, support services committee, medical services committee, community awareness committee, and quality assurance and evaluations committee (CARE Council Bylaws, 2013, p.9). Each of these committees perform unique functions that promote 
realization of the intents and purposes of the CARE Council. Furthermore, the CARE Council occasionally create ad hoc committees as needed to attend to pertinent issues to enhance performance of its roles and responsibilities. For instance, the CARE Council sometimes uses an ad hoc committee to assist in the planning of the annual retreat.

The annual retreat of the CARE Council serves as a viable avenue for collaborative governance. As a forum for inclusive representation, education, deliberation, and strategic planning, the retreat provides a unique space for divergent and convergent thinking on various issues pertinent to care and treatment of target populations in the county. The consistency with which the CARE Council and other key stakeholders organize and execute the retreat over the years attests to its unique contributions to health services collaborative governance for care and treatment of target populations.

The retreat represents one of the key aspects of ensuring participation in collaborative governance at an Eligible Metropolitan Area (EMA). This regular annual event extends representation and participation in collaborative governance beyond the established three (3) core groups of the CARE Act and local policies and procedures (CARE Council Bylaws, 2005; CARE Act, 1990), and enables perspectives of various stakeholders for creative solutions for care and treatment. To some extent, the retreat exemplifies an inclusive participation forum of cross-sector stakeholders in collaborative governance.

The retreat provides an opportunity for interaction among various stakeholders in seven-to-eight (7-8) hour time frame and consists of multiple sessions. This once-in-a-year event provides a unique opportunity to some stakeholders to make meaningful contributions to the CARE Council's overall efforts in each grant year. In the past few years, some of the themes addressed at the annual retreat include cultural competency, role of advocacy on HIV/AIDS, collaborative engagement and collaborative leadership, care and treatment regimes, continuum of care, system of care, future of the CARE Act, pertinent emergent issues on HIV/AIDS, code of ethics on health services, role of the Council in the fight against HIV/AIDS, building collaborative capacity for care and treatment, and health systems challenges (CARE Council, 2016; CARE Council Comprehensive Plan, 2012).

At the retreat, professionals and/or experts facilitate discussions and group activities among the stakeholders to help formulate strategies for the way forward for pertinent care and treatment services. The strategies are further developed and acted on by the CARE Council. Thus, the retreat outputs are discussed by the various committees of the CARE Council with specific assigned tasks to committees to enhance care and treatment efforts. The retreat efforts usually set the stage for the rest of CARE Council's undertakings in each grant year.

To some extent, the annual retreat of the CARE Council helps promote outputs based on inputs from crosssector stakeholders. By bringing together various stakeholders including council members, agency officials, community advocates, key individuals and other relevant stakeholders in a structured, but flexible forum of engagement, encourages dialogue and formulation of workable solutions for the benefits of target populations. The benefits emanating from the annual retreat would fall into both process, and output/outcome categories, and thereby help relate the extant literature suppositions on collaborative engagement in addressing complex problems (Carlson, 2007; Fung 2006; Bryson et al., 2006). This study which aims to examine the role of an annual retreat to CARE Council's collaborative governance will rely on data from interviews, observations, and review of documents to draw some insightful conclusions in an attempt to provide possible answers to the question: how does Palm Beach County's HIV CARE Council's annual retreat enables HIV/AIDS collaborative governance? The next section of this paper will focus on methods used in the data collection and will be followed by analysis and discussion of findings, conclusions, and implications.

\section{Methodology}

This study uses a case study approach to examine the phenomenon of an annual retreat by the Palm Beach County's HIV CARE Council (CARE Council) as part of collaborative governance for care and treatment of target populations. For decades, the CARE Council has successfully organized the annual retreat to generate relevant outputs and/or outcomes to effectively complement care and treatment efforts through collaborative engagement of various stakeholders. The focus on the annual retreat helps to ascertain the nature of multi-stakeholder engagement for collective problem solving. Many scholars highlight how the use of a case study approach to examine phenomenon of interest enable discoveries (Yin, 2003; Stake, 1998; Bennett \& George, 2005 Gerring, 2004; Thomas, 2003; Hamel et al., 1998; Jensen \& Rogers, 2001; Baxter \& Jack, 2008; Ospina \& Dodge2005). The contributions of case study to scholarly inquiry in public administration cannot be overemphasized. Stake (1998) points out how case study enables using multiple ways to obtain answers in relation to a phenomenon of interest; Yin (2003), Thomas, (2003), and Hamel et al. (1993) underscore answers to 'how' and 'why' questions because of a case study; and Jensen and Rogers (2001) accentuate uniqueness of conditional findings and deciphering of cause and effect relationships through case study, which can be hardly achieved when using other methodologies. Generally, case study promotes understanding of phenomenon and theory building through essential discoveries (Bennett \& George, 2005; Saldana \& Omasta, 2017).

This case study relies on interview of CARE Council members, the Grantee and other key stakeholders in collaborative governance and is triangulated with review of documents and observations. The participants occupy 
unique roles at the Council, agencies and communities in Palm Beach County. Most of the participants have participated in the annual retreat for at least a decade and perceived their participation as an enriching experience. These participants' perspectives are essential to knowledge and understanding of the use of an annual retreat as an avenue to foster performance of CARE Council's roles and responsibilities through strategic engagement and strategic planning involving relevant cross-sector stakeholders.

There were a total of ten (10) in-depth interviews conducted by the authors from June 2016 to May 2017. The participants were mostly CARE Council and committee members. Six of the participants were female and four were male, and on average, each participant has been part of the Council for at least ten years. Each participant was asked a series of questions that revolved around the annual retreat and its role to the CARE Council's collaborative governance. The questions were semi-structured and presented each participant an opportunity to provide additional useful details to help achieve the objectives of the study. The interviews were conducted at the convenience of the participants, and relevant research protocols were followed to promote confidentiality and the integrity of the study (DiCicco-Bloom \& Crabtree, 2006). The in-depth nature of the interviews (at least, an hour and half per each interview session) enabled rich conversations with participants which provided needed data on the participants' retreat experiences and thereby created meaning as expected of qualitative interviews (Yin, 1984; Rubin \& Rubin, 1995; Hostein \& Gubrium, 1999; Saldaña \& Omasta, 2017). In particular, the interviews provided useful information regarding how participation, representation, and outputs of the annual retreat complement the work of the Council as it relates to making various decisions and allocation priorities for various service categories to promote health and general wellbeing of the target populations.

In an attempt to construct a narrative that better represents the annual retreat experience of the participants, data from the interviews are triangulated with observation of various CARE Council annual retreats by the authors, at least 6 within a period of 10 years $(2009 ; 2014 ; 2015 ; 2016 ; 2018 ; \& 2019)$. The authors closely observed the various presentations and attendant discussions among stakeholders, stakeholder participation in the various group activities, facilitation of group activities, interactions at various tables and other activities aimed at effectively engaging participants. Furthermore, documents related to the annual retreat such as the agenda, group activity reports, and presentation handouts were reviewed for additional insights. Scholars such as Greene et al. (1989), Flick (2004), and Jick (1979) articulate how the use of different methods enable generation of data that complement and help triangulate perspectives on the issue or phenomenon of study. For instance, Salkind (2009) highlights how observation of a study's context and participants help create meaning about the phenomenon of interest. For the analysis and reporting of findings, the study will mostly utilize interview data with complementary themes from review of documents and authors' observation notes. Overall, the data and analysis which involve coding, developing themes and categories, and integration would promote knowledge and understanding of the role that the CARE Council's annual retreat plays in collaborative governance to address the HIV/AIDS conundrum in the county.

\section{Analysis and Discussion}

The rationale for this research is to ascertain the role of an annual retreat as a key aspect of HIV/AIDS collaborative governance in South Florida, specifically in Palm Beach County. The annual retreat serves as a strategic forum of engagement involving various key stakeholders in formulating strategies to help provide needed care and treatment to HIV/AIDS infected and affected persons. The extent of participation by various groups including service providers, non-elected community leaders, target populations, policy entrepreneurs, key individuals, other relevant publics, private and nonprofit entities among others, promotes robust discussions, deliberations and measures in a way that complement the work of the CARE Council. Data that was collected through interviews, observations, and review of documents were coded and developed into themes, categories and concepts in compliance with qualitative research expectations (Saldaña \& Omasta, 2017; Hostein \& Gubrium, 1999; Yin 2003; DiCicco-Bloom $\&$ Crabtree, 2006). The analysis thereby represents synthesis of the derived categories, concepts and themes that emerged from the data which helps to provide insights into the role of an annual retreat to CARE Council's collaborative governance. Thus, the following segments of the paper highlights themes such as strategic preparation, inclusive participation, retreat as an educational moment, evolution of the retreat, and cultural humility in a quest to decipher retreat's strategic impact on CARE Council's collaborative governance as it relates to care and treatment of HIV/AIDS infected and affected populations. These themes would help answer the research question: how does Palm Beach County's HIV CARE Council's annual retreat enables HIV/AIDS collaborative governance? The expectation is that answers to the question would promote knowledge and understanding of the role of an annual retreat as a key forum for collaborative governance in the fight against HIV/AIDS.

\subsection{Strategic Preparation}

Preparation is key to effective engagement, especially if it is well thought out and involves relevant stakeholders in the planning process for a forum such as an annual retreat. The process of soliciting insights and participation of critical stakeholders through a series of face-to-face deliberations and other mediums of information exchange 
help to generate an agenda that enables realization of goals and objectives of the retreat. Scholars such as Bryson et al. (2006), Ansell and Gash (2008), Crosby and Bryson (2012), Quick and Feldman (2014), Bryson et al. (2008), Simo and Bies (2007), and Clarke and Fuller (2010) highlight how strategic preparation promotes realization of goals and objectives of collaborative governance in addressing complex problems.

The responses of participants to questions related to preparation for the retreat point to intense deliberations involving various key stakeholders, generation of relevant themes for the retreat, strategy formulation for problem solving, logistics and agenda setting, learning and commitment for collective action, team building exercise, and innovation in care coordination. For instance, one participant points out:

County, health council staff, CARE Council representatives on committees and other volunteers review what was done previously and what emergent issues they are dealing with currently and decide various details of what needs to be addressed at the retreat. These days, clients are involved in planning for the retreat and others are asked to participate based on expertise, interest, and everyone is accommodated as no one is turned away.

This response appears to suggest preparation for the retreat as a team effort involving various stakeholders who help set the agenda in a way that would promote effective engagement, learning and formulation of solutions to problems in the context of collaborative governance.

\subsection{Inclusive participation}

Inclusive participation in collaborative governance, particularly as it relates to engagements at a forum such as an annual retreat is likely to promote creative ideas, commitment, and sustainable solutions to a complex problem which in this case is the HIV/AIDS conundrum. Bringing together stakeholders from public, private, civic/nonprofit sectors who are directly or indirectly involved in the provision of health services in a collaborative process encourages formulation of strategies which could translate into allocation priorities for various service categories. The literature on inclusive participation in collaborative governance highlights how stakeholders build and draw on their collective strengths to navigate challenges and generate workable solutions in collective problem solving (Huxham and Vangen 2005; Bryson et al., 2015; Berardo, Heikkila, and Gerlak 2014; Saz-Carranza and Ospina 2011; Cheng \& Daniels, 2005; Ansell \& Gash, 2008; Emerson et al., 2015; Margerum, 2011)

Responses by participants to questions gauging the extent of participation suggest organizers are intentional in reaching out to various relevant stakeholders i.e. groups, individuals, including consumers of services, nonRyan White service providers, CARE Council members, and other interested parties. Furthermore, the responses seem to suggest an inclusive retreat promotes formulation of strategies and solutions for care and treatment, encourages open conversation and divergent viewpoints among stakeholders, serves as a reunion among stakeholders to renew their commitment to the fight against HIV/AIDS, fosters teamwork, and enhances understanding of the CARE Council's roles and responsibilities, achievements and challenges. The response below by one participant epitomizes perspectives on inclusive participation in the annual retreat:

Agencies that do not know much about AIDS but provide services participate to increase awareness and could join CARE Council as a result. Agencies that know about AIDS also participate. Leaders and politicians, bureaucrats etc. are occasionally part of it. Key staff also attend. Participants provide better perspectives on issues including sharing perspective on HIV/AIDS services with providers and non-providers of HIV/AIDS services. Clients who are not members also get to learn what is being done, learn about services and what they can do to contribute to the process. The retreat is inclusive not exclusive as all relevant parties are invited each year.

This response highlights the extent of stakeholders' engagement at the annual retreat and the diverse perspectives that are shared to help formulate care and treatment strategies. Observation of various retreats to a large extend attests to their inclusive and integrated nature. The respondent's assertion on inclusiveness points to openness in including other groups in the retreat as emergent and needed for effective collective action on HIV/AIDS.

\subsection{Evolution of the retreat}

Evolution in collaborative governance whether in the areas of annual forum such as a retreat or otherwise shows that evidence-based changes to establish goals and objectives can be better achieved for the common good. This means that changing dynamics of HIV/AIDS epidemic over the years needs adaptive approaches even in the process of engagement associated with care and treatment to ensure acceptable outputs and/or outcomes. Scholars such as Provan and Kenis (2008), Thomson and Perry (2006), Plotnikof (2016), Bryson et al., (2015), Purdy (2012), Vangen \& Winchester (2013) underscore organic or necessitated evolution and/or changes associated with multistakeholder engagement for collective problem solving. 
Responses of participants to questions related to progression of the retreat suggest evolution in terms of category of participants, consistency of stakeholder engagement, focus on trending and emergent issues important to care and treatment, evolution of intensity and hours/duration of stakeholder engagement at the retreat, and progression from focus on medication needs to holistic and communal needs of infected and infected populations. The responses seem to suggest there is now a focus on divergent and tailored presentations, expertise, concentrated changes in programmatic areas and system of care while remaining consistent in putting the event together, evolution in importance and setting priorities, and overall changes in a positive direction. Relatedly, observation of the retreat over the years point to incremental progression in participation in ways that foster common resolve for collective action on HIV/AIDS. The response below shows how the CARE Council retreat as an annual forum of stakeholders' engagement has evolved over the years.

There used to be a handful of people at the retreat but now more people are

getting involved. In the beginning folks were dying of HIV/AIDS and we were

helping them to die with dignity. The retreat has grown with knowledge and

expertise. We are no longer focusing on helping clients get services and die with

dignity, we do more than that. We now focus on services that meet essential needs

in view of growth and maturity of HIV/AIDS and associated issues and services.

The statement above appears to reiterate the versatility of the CARE Council when it comes to the annual retreat, particularly the aspect of intentional changes to ensure adaptability to emergent issues on HIV/AIDS as a conduit to promote care and treatment of target populations through various service categories.

\subsection{Retreat as an educational moment}

The nature of multi-stakeholder engagements at the annual retreat appears to serve as an educational moment for all participants including CARE Council members. The diverse representation of stakeholders and perspectives, the various topics of presentation and deliberation, and group activities seem to promote knowledge and understanding of collaborative governance for care and treatment of target populations. Scholars such as Plotnikof (2016), Bryson et al. (2015), Leach, Weible, Vince, Siddiki, \& Calanni (2013), Kooiman (1993), Sirianni (2009), and Beierle \& Cayford (2002) point out how multi-stakeholder engagement in established forums help grow knowledge and understanding of inclusive structures and processes, and enable viable solutions for change and collective problem solving, especially complex ones.

Responses from participants to questions geared toward the educational benefits of participation in the annual retreat seem to suggest consensus among participants on the influence of the various topics of presentation and discussion over the years i.e. diversity and inclusion, collaboration and leadership, code of ethics, cultural competency, effective deliberation, resilience through peer support, efforts to stop HIV and find cure, how to fight stigma, care and treatment expectations, management of continuum of care, and the benefits and challenges related to members' knowledge and understanding of HIV/AIDS collaborative governance. Furthermore, the participants appear to acknowledge how the annual retreat is empowering, promotes networking among stakeholders, exposes various stakeholders to the roles and responsibilities of the CARE Council, helps develop key competencies, and encourages participation and decision making. A comment by one respondent suggests:

The annual retreat helps grow knowledge of decision makers, complement

training workshops that are provided to members throughout the year and helps

Council members make data driven decisions.

The above statement highlights the educational benefits of the annual retreat to collaborative governance, which seems to indicate fostering care and treatment of HIV/AIDS infected and affected at the county.

\subsection{Cultural humility}

Observation of multi-stakeholder engagement at the annual retreat and comments from the participants during the interviews seem to suggest intentional efforts to understand the 'other' as a conduit to promote collaborative governance for HIV/AIDS care and treatment. Cultural humility which is defined as "having an interpersonal stance that is other-oriented rather than self-focused, characterized by respect and lack of superiority toward an individual's cultural background and experience" (Hook, Davis, Owen, Worthington, \& Utsey, 2013, p.353) appears to be palpable in how various stakeholders engage each other at the annual retreat. Over the years, efforts have been made to listen to key populations and participants in order to better understand their narratives, perspectives, issues, and concerns to help formulate strategies for care and treatment. Furthermore, the retreat provides the opportunity for service providers, non-elected community leaders, and county officials to interact with HIV/AIDS infected and affected individuals in an environment that is safe, encouraging and embracing of a difference in a collaborating setting geared toward formulating solutions for health and general wellbeing of target populations. A statement by one of the respondents' notes that the success of the retreat is based on respect for consumers of services and the desire to empower them to be effective leaders in HIV/AIDS arena, seems to convey the extent to which cultural humility is embraced at the retreat. 
Research by Yeager and Bauer-Wu (2013), Alsharif (2012), Foronda and Baptiste (2016) Chang, Simon, and Dong (2012), Foster (2009), Cruess \& Cruess (2010), and Isaacson (2014) points to how operating from a standpoint of cultural humility nurtures effective engagement of relevant stakeholders. These scholars allude to how cultural humility serves as a better alternative to cultural competency in helping to effectively engage key constituencies in collective problem solving. The experience of the annual retreat as it relates to engagement of key populations and the consistency of intentional efforts to harness various expertise and experiences for sustainable solutions within the context of collaborative governance for care and treatment, appears to be helpful.

\section{The Annual Retreat's Impact on the Work of the Care Council}

The role of an annual retreat to the CARE Council's collaborative governance is critical for care and treatment efforts in Palm Beach County. The use of the retreat as an avenue for collaborative governance seems to promote purposeful multi-stakeholder engagement around established agenda in a way that enables formulation of goals and strategies for delivery of various category of services to target populations. For instance, the use of group activities involving various stakeholders at the 2016 CARE Council Annual Retreat to collectively formulate strategies for care and treatment served as a critical component of the CARE Council's 5-Year Integrated Plan (CARE Council 2016) and laid the foundation for most of the tasks of the various committees of the CARE Council and the CARE Council itself in the grant year. Similarly, presentation and discussion of key issues and topics during past retreats, i.e. cultural competency, diversity and inclusion, leadership and collaboration, management of continuum of care, future of Ryan White CARE Act, health systems challenges serve as an invaluable educational moments and complement existing capacities of members and the CARE Council.

The diagram below depicts the role of the annual retreat in collaborative governance of the CARE Council. It relates participation of state and non-sate stakeholders including target populations such as healthcare providers, social service providers, local agencies, community-based organizations, affected communities, individuals with AIDS, Grantee, and non-elected community leaders. These stakeholders' engagement at the retreat and CARE Council enable outputs such as allocation priorities for various service categories, integrated plans, and needs assessment reports. For instance, the outputs of the 2016 retreat, especially generated documents based on group activities by the various stakeholders, allowed the various CARE Council committees to develop strategies and performed tasks relevant to the completion of the 5-Year Integrated Plan. Thus, there is some connectedness between stakeholders' involvement in planning for the retreat, eventual engagement at the retreat and CARE Council, and attendant outputs which usually translate into services to those infected and affected. For example, from 2000-2006 timeframe, the CARE Council allocated \$63,830,957 and \$43,151,318 in 2009-2013 for the provision of various category of services annually to about 5,143 and 3,049 people respectively in need of care (Agbodzakey, 2017; CARE Council Comprehensive Plan, 2006; CARE Council Compiled Allocation Priorities, 2014a; CARE Council Count of Clients \& Services Report, 2009; 2014b).

Figure 1: The CARE Council Retreat Model

Stakeholders Engagements

Outputs

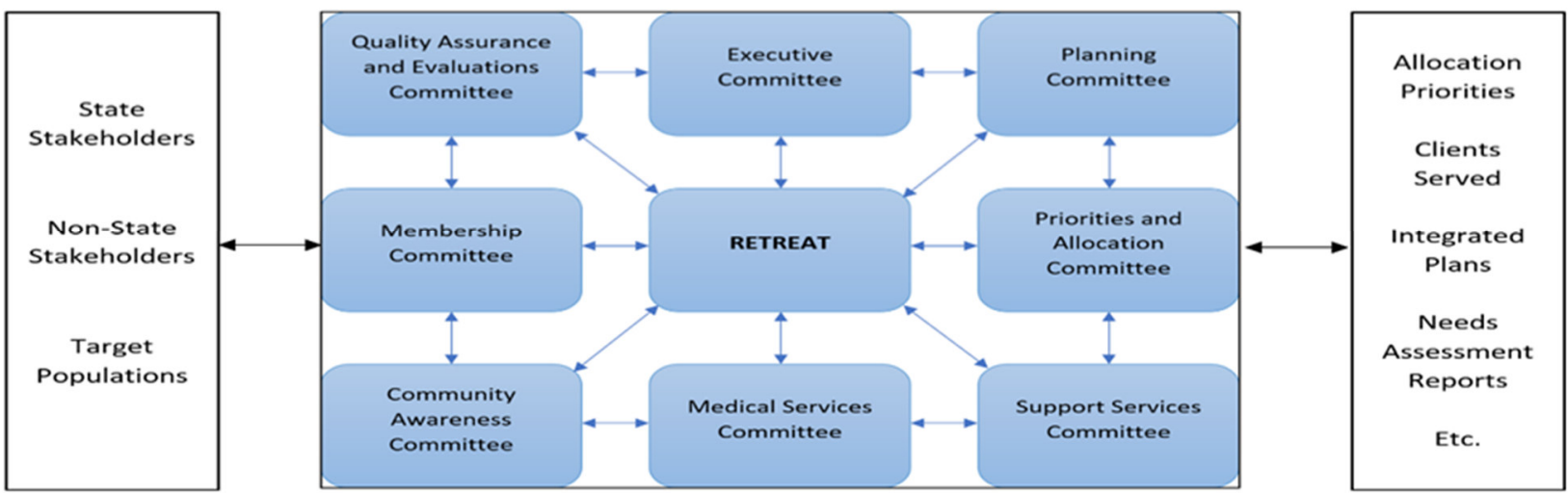

Source: Model designed by the authors

The role of collaborative governance in the CARE Council's annual retreat in the HIV/AIDS arena shows (a) for retreats, strategic preparation enable constructive multi-stakeholder engagements; (b) the inclusive nature of the forum consisting of service providers, target populations, non-elected community stakeholders and other critical partners in the fight against HIV/AIDS; (c) the evolving nature of events that embodies progress at various HIV/AIDS fronts through various intentional and strategic engagements; (d) an educational moment that help to grow stakeholders' capacity, knowledge and task performance; and (e) a gathering that promote tolerance and understanding of the "other" in a quest for meaningful and sustainable solutions to the complex HIV/AIDS problem. In summary, the role of collaborative governance in the CARE Council's annual retreat highlights its essential role in generating resource pool, commitment, networking, shared understanding, communication, 
consensus and strategic plans among actual and some potential players in the HIV/AIDS arena for the common good. While the annual retreat represents a whole day (seven-to-eight hour) event in a year, it also helps to shape the focus of other key partners working directly or indirectly to promote care and treatment.

To some extent, the retreat helps to renew the collaborative spirit among stakeholders, fosters new initiatives and engagements, instigates provision of needed services to target populations who are not currently in the continuum of care, and broadens overall efforts to keep the focus on HIV/AIDS. This appears to be a conduit to sustain preventative and remedial, if not curative measures. The retreat is more of a strategic engagement that enables strategic planning by relevant stakeholders to vigorously tackle current and emergent challenges associated with the HIV/AIDS epidemic. Evidently, there is somewhat consensus among scholars on the strategic use of collaborative governance by cross-sector stakeholders to develop capacity, workable measures, and competencies to foster effective solutions to complex problems, which in this case, is the HIV/AIDS conundrum (Weber \& Khademian 2008; Quick and Feldman 2014; Simo 2009; Simo \& Bies 2007; Ritvala, Salmi \& Andersson, 2014; Bryson et al. 2008; Babiak and Thibault 2009; Crosby and Bryson 2012, and Agranoff, 2012). The case of the CARE Council and the well-intended annual retreat appears to be a truly progressive undertaking to shape current and future efforts in the fight against HIV/AIDS in Palm Beach County.

Undoubtedly, leadership is equally key in the progress and success of the annual retreat. A closer examination of the CARE Council's annual retreat attests to the key role of facilitative leadership in ensuring collaborative success. Facilitative leadership in this context implies catalytic efforts of leaders from the initial planning of the retreat to post retreat activities by the CARE Council. The nonconventional nature of leadership in the CARE Council's collaborative governance accentuated the viability of cross-sector and multi-stakeholder engagements as it used a lateral leadership mechanism highlighted in research by Freeman 1997; Margerum 2002; Lasker and Weiss 2003; Murdock, Wiessner, and Sexton 2005; Ansell \& Gash, 2008; Huxham and Vangen 2000; and Imperial 2005, to formulate workable solutions. Facilitative leadership in this case also ensured representation, participation, and empowerment of otherwise usually excluded groups and thus provides useful insights for emergent multistakeholder arrangements geared toward solving complex problems (Agbodzakey, 2012; Vangen \& Huxham, 2003, and Ansell and Gash, 2008).

\section{Conclusion and Implication}

The complex nature of the HIV/AIDS epidemic calls for innovative approaches to address associated challenges, one of which is care and treatment of infected and affected populations. The multifaceted nature of the problem and the domino impact on various sectors of a country's economy necessitated collective action from all relevant stakeholders. Collaborative governance which promotes intentional engagement of cross-sector stakeholders for creative solutions to complex problems, has become a commonly utilized approach in the past few decades. In the case of HIV/AIDS in the U.S., the enactment of the Ryan White Comprehensive AIDS Resource Emergency Act (CARE Act) in 1990 with a key aspect that focuses on care and treatment of target populations enabled collaborative governance for allocation priorities to various service categories for those infected and affected.

The HIV/AIDS CARE Council of Palm Beach County which is a health services planning council, embraced the use of collaborative governance over the years to foster effective and constructive decisions for care and treatment with annual retreat as one of the key components. This study examines the use of an annual retreat by the CARE Council as an avenue for collaborative governance to ascertain its role in enabling the fulfilment of legislative intents to benefit target populations. The results suggest that annual retreat serves as a unique opportunity for collaborative governance in promoting strategic preparation that enables strategic stakeholder engagement for innovative health services delivery to target populations through enhanced CARE Council roles and responsibilities. Furthermore, the results highlight how the annual retreat helps to develop needed capacity, mutual commitment, and competencies for creative inputs, outputs and/or outcomes related to the HIV/AIDS problem. It is equally apparent that openness and intentional engagement of all relevant stakeholders, especially otherwise usually excluded groups, promote common resolve and sustainable solutions with facilitative leadership serving as a lynchpin to all of the integrated efforts to purposeful ends. As such, collaborative governance represents a viable alternative approach to the usually mainstream top-down management when it comes to addressing community crises and/or complex problems with or without an established legislative mandate. The efforts of the CARE Council within a local system context represents an essential part of the U.S. government's commitment to tackle the HIV/AIDS problem and to promote health and general wellbeing of infected and affected populations. While the study's findings cannot be generalized to other Eligible Metropolitan Areas (EMAs) in the U.S. and its territories because of the uniqueness of the experience at Palm Beach County, it does offer insights into the likely benefits of embracing intentionally inclusive multi-stakeholder engagement event on a consistent basis as a conduit to collective problem solving. Future research could examine the use of an annual retreat in a comparative perspective within the context of collaborative governance and other complementary workshops/training efforts at EMAs to help establish some connectedness to care and treatment outputs and/or outcomes. A scholarly project of this nature would boost the case for the viability of cross-sector collaboration for 
complex problem solving in emergent and established economies and democracies.

\section{References}

Agbodzakey, J. (2012). Collaborative governance of HIV health services planning councils in Broward and Palm Beach Counties of South Florida. Public Organiz Rev, 12(2), pp.107-126.

Agbodzakey, J. (2015). Ryan White CARE Act and HIV/AIDS services collaborative governance: The South Florida experience. LAP/OmniScriptum

Agbodzakey, J. (2017). Ryan White CARE Act and collaborative governance re-examined: the South Florida experience. Public Organiz Rev, 17(2), pp.293-314

Agranoff, R. (2012). Collaborating to manage: A primer for the public sector. Washington, DC: Georgetown University Press

Alsharif, N. Z. (2012). Cultural humility and interprofessional education and practice: A winning combination. American journal of pharmaceutical education, 76(7), p.120

Anonymous. (2006). A call to scholars and teachers of public administration, public policy, planning, political science, and related fields. Public Administration Review, 66(6), pp.168-170

Ansell, C., \& Gash, A. (2008). Collaborative governance theory and practice. JPART, 18(4), pp.543-571

Babiak, K., \& Thibault, L. (2009). Challenges in multiple cross-sector partnerships. Nonprofit and voluntary sector quarterly, 38(1), pp.117-143

Baxter, P., \& Jack, S. (2008). Qualitative case study methodology: Study design and implementation for novice researchers. The qualitative report, 13(4), pp.544-559

Beierle, T. C. (2000). The quality of stakeholder-based decisions: Lessons from the case study record. Discussion Paper 00-56, Resources for the Future.

Beierle, T.C., \& Cayford, J. (2002). Democracy in practice: public participation in environmental decisions. Washington, DC: Resources for the Future.

Bel, G. \& Warner. M. (2008). Does privatization of solid waste and water services reduce costs? A review of empirical studies. Resources, Conservation and Recycling 52 (12):1337-48.

Bennett, A., \& George, A. L. (2005). Case studies and theory development in the social sciences. Cambridge, Mass.

Berardo, R., Heikkila, T., \& Gerlak, A. K. (2014). Interorganizational engagement in collaborative environmental management: Evidence from the South Florida ecosystem restoration task force. JPART, 24(3), pp.697-719

Bertelli, Anthony M., and Craig R. Smith. (2010). Relational contracting and network management. JPART, 20(suppl_1), pp.i21-i40

Bingham, L. B., \& O'Leary, R. (2008). Big ideas in collaborative management. New York: M.E Sharpe

Booher, D. E. (2004). Collaborative governance practices and democracy." National Civic Review, 93(4), pp.3246

Bryson, J. M., Crosby, B. C., \& Stone, M. M. (2006). The design and implementation of cross-sector collaborations: Propositions from the literature. Public Administration Review, 66(Special Issue), pp.44-55.

Bryson, J, M., Crosby, B. C. Stone, M. M. \& Mortensen, J.C. (2008). Collaboration in fighting traffic congestion: A study of Minnesota's urban partnership agreement. Report no. CTS 08-25, Center for Transportation Studies, University of Minnesota. Retrieved on October 4, 2017 from http://www.cts.umn.edu/Publications/ResearchReports/reportdetail.html?id=1714

Bryson, J. M., Crosby, B. C., \& Stone, M. M. (2015). Designing and implementing cross-sector collaborations: Needed and challenging. Public Administration Review, 75(5), pp.647-663

Carlson, C. (2007). A practical guide to collaborative governance. Portland, OR: Policy Consensus Initiative.

Centers for Disease Control and Prevention-CDC (2017). HIV in the United States: At A Glance. Retrieved on October 4, 2017 from https://www.cdc.gov/hiv/statistics/overview/ataglance.html

Cheng, A. S., and S. E. Daniels. (2005). Getting to 'we': examining the relationship between geographic scale and ingroup emergence in collaborative watershed planning. Human Ecology Review 12: pp.30-43.

Chang, E. S., Simon, M., \& Dong, X. (2012). Integrating cultural humility into health care professional education and training. Advances in health sciences education, 17(2), pp.269-278.

Choi, T., \& Robertson, P. J. (2014). Deliberation and decision in collaborative governance: a simulation of approaches to mitigate power imbalance. JPART, 24(2), 495-518

Chrislip, D, \& Larson. C. E. (1994). Collaborative leadership: How citizens and civic leaders can make a difference. San Francisco, CA: Jossey-Bass.

Clarke, A, \& Fuller, M. (2010). Collaborative strategic management: strategy formulation and Implementation by multi-organizational cross- sector social partnerships. Supplement, Journal of Business Ethics, 94, pp.85-101

Crosby, B.C., \& Bryson. J. M. (2012). Integrative leadership and policy change: a hybrid relational view. in advancing relational leadership research: a dialogue among perspectives, edited by Mary Uhl-Bien and Sonia M. Ospina, 303-33. Charlotte, NC: Information Age. 
Cruess, S. R., Cruess, R. L., \& Steinert, Y. (2010). Linking the teaching of professionalism to the social contract: A call for cultural humility. Medical teacher, 32(5), pp.357-359

Daniel, J. R., Pinel, S. L., \& Brooks, J. (2013). Overcoming barriers to collaborative transboundary water governance. Mountain Research and Development, 33(3), pp.215-224.

DiCicco-Bloom, B., \& Crabtree, B. F. (2006). The qualitative research interview. Medical education, 40(4), pp.314-321

Donahue, J. D., \& Zeckhauser. R. (2011). Collaborative governance: Private roles for public goals in turbulent times. Princeton, NJ: Princeton University Press.

Emerson, K., Nabatchi, T., \& Balogh, S. (2012). An integrative framework for collaborative governance. JPART, 22(1), 1-29

Flick, U. (2004). Triangulation in qualitative research. A companion to qualitative research, pp.178-183

Foronda, C., Baptiste, D. L., Reinholdt, M. M., \& Ousman, K. (2016). Cultural humility: A concept analysis. Journal of Transcultural Nursing, 27(3), pp.210-217.

Foster, J. (2009). Cultural humility and the importance of long-term relationships in international partnerships. Journal of Obstetric, Gynecologic, \& Neonatal Nursing, 38(1), pp.100-107.

Freeman, J. (1997). Collaborative governance in the administrative state. UCLA Law Review, 45, p.1

Fung, A. (2006). Varieties of participation in complex governance. Public Administration Review, 4(1), pp.286289

Fukuyama, F. (2013). What is governance? Governance, 26(3), pp.347-368.

Gerlak, A. K., Lubell, M. \& Heikkila.T. (2012). The promise and performance of collaborative governance. In Oxford Handbook of US Environmental Policy, eds. Sheldon

Kamieniecki, and Michael E. Kraft. Oxford, UK: Oxford University Press, 413-34.

Gerring, J. (2004). What is case study and what is it good for? American Political Science Review, 98(2), pp.341354.

Gray, B. (1989). Collaborating: Finding common ground for multiparty problems. San Francisco. Jossey-Bass

Greene, J. C., Caracelli, V. J., \& Graham, W. F. (1989). Toward a conceptual framework for mixed-method evaluation designs. Educational Evaluation and Policy Analysis, 11(3), pp.255-274

Hageman, W. M., \& Bogue, R. J. (1998). Layers of leadership. The challenges of collaborative governance. Trustee, 51(8), pp.18-20

Hamel, J., Dufour, S., \& Fortin, D. (1993). Case Study Methods. Thousand Oaks, CA. Sage

Healey, P. (1997). Collaborative planning: Shaping places in fragmented societies. Vancouver: UBC

Holstein, J. A., \& Gubrium, J. F. (1999). Active interviewing. In Alan Bryman and Robert G. Burgess, eds. Qualitative Research, Vol II: London

Hook, J. N., Davis, D. E., Owen, J., Worthington, E. L., Jr., \& Utsey, S. O. (2013). Cultural humility: Measuring openness to culturally diverse clients. Journal of Counseling Psychology, 60(3), p.353- 366

Huxham, C., \& Vangen, S. (2000). Leadership in the shaping and implementation of collaboration agendas: How things happen in a (not quite) joined-up world. Academy of Management Journal, 43(6), pp.1159-1175

Huxham, C, and Vangen, S. (2005). Managing to collaborate: the theory and practice of collaborative advantage. New York: Routledge

Imperial, M. T. (2005). Using collaboration as a governance strategy lessons from six watershed management programs. Administration \& Society, 37(3), 281-320

Isaacson, M. (2014). Clarifying concepts: Cultural humility or competency. Journal of Professional Nursing, 30(3), pp.251-258.

Jensen, J. L., \& Rodgers, R. (2001). Cumulating the intellectual gold of case study research. Public Administration Review, 61(2), pp.235-246

Jick, T. D. (1979). Mixing qualitative and quantitative methods: Triangulation in action. Administrative Science Quarterly, 24(4), pp.602-611.

Johnston, E. W., Hicks, D., Nan, N., \& Auer, J. C. (2011). Managing the inclusion process in collaborative governance. JPART, 21(4), pp.699-721.

Karkkainen, Bradley C. 2002. Collaborative ecosystem governance: Scale, complexity, and dynamism.Virginia Environmental Law Journal 21, pp.189-243

Kooiman, J. (1993). Modern governance: new government-society interactions, New York: Sage

Lasker, R. D., \& Weiss, E. S. (2003). Broadening participation in community problem-solving:

A multidisciplinary model to support collaborative practice and research. Journal of Urban Health: Bulletin of the New York Academy of Medicine 80(1), pp.14-47.

Leach, W. D. (2006). Collaborative public management and democracy: Evidence from Western watershed partnerships. Public Administration Review 66(s1), pp.100-110.

Leach, W. D., Weible, C. M., Vince, S. R., Siddiki, S. N., \& Calanni, J. C. (2013). Fostering learning through collaboration: Knowledge acquisition and belief change in marine aquaculture partnerships. Journal of Public 
Administration Research and Theory, 24(3), pp.591-622

Lynn, L., Jr., Heinrich, C., \& Hill, C. (2000). Studying governance and public management: Why? How?

In G. H. Frederickson \& K. B. Smith (Eds.), The public administration theory primer (p. 210). Boulder: Westview

Margerum, R. D (2002). Collaborative planning: Building consensus and building a distinct model for practice. Journal of Planning Education and Research 21(3), pp.237-253

Margerum, R. D. (2011). Beyond consensus: Improving collaborative planning and management. MIT Press

McGuire, M. (2006). Collaborative public management: Assessing what we know and how we know it. Public Administration Review. 66(Special Issue), pp. 33-43

Memon, P. A., \& Kirk, N. A. (2010). Barriers to collaborative governance in New Zealand fisheries: Pt I. Geography Compass, 4(7), pp.778-788

Metze, T., \& Levelt, M. (2012). Barriers to credible innovations: Collaborative regional governance in the Netherlands. The Innovation Journal, 17(1), p.2

Michalski, W., Miller, R., \& Stevens, B. (2001). Governance in the 21 st century. Future Studies, OECD Publication. Retrieved December, 2008 http://www.oecd.org/dataoecd/15/0/17394484.pdf.

Murdock, B. S., Wiessner, C., \& Sexton, K. (2005). Stakeholder participation in voluntary environmental agreements: Analysis of 10 Project XL case studies. Science, technology, \& human values, 30(2), pp.223250 .

Ospina, S. M., \& Dodge, J. (2005). Narrative inquiry and the search for connectedness: Practitioners and academics developing public administration scholarship. Public Administration Review, 65(4), 409-423.

Palm Beach County CARE Council. (2005). Byelaws. Palm Beach County, Florida

Palm Beach County CARE Council. (2006). Palm Beach County EMA comprehensive plan. Palm Beach County, Florida

Palm Beach County CARE Council. (2009). Count of clients and service report. Palm Beach County, Florida

Palm Beach County CARE Council. (2012). Palm Beach County EMA comprehensive plan. Palm Beach County, Florida

Palm Beach County CARE Council. (2013). Byelaws. Palm Beach County, Florida

Palm Beach County CARE Council. (2014). Count of clients and service report. Palm Beach County, Florida

Palm Beach County CARE Council. (2014a). Compiled allocation priorities, FY 2009-2013. West Palm Beach EMA. Palm Beach County, Florida

Palm Beach Country CARE Council. (2014b). Ryan White part A count of clients and service report.

Palm Beach County, Florida

Palm Beach County CARE Council. (2016). Palm Beach County integrated prevention and patient care plan. Palm Beach County, Florida.

Plotnikof, M. (2016). Letting go of managing? Struggles over managerial roles in collaborative governance. Nordic Journal of Working Life Studies, 6, 109

Provan, K. G., \& Kenis, P. (2008). Modes of network governance: Structure, management, and effectiveness. , JPART 18(2), pp.229-252.

Purdy, J. M. (2012). A framework for assessing power in collaborative governance processes. Public Administration Review 72(3), pp.409-417

Quick, K.S., \& Feldman, M. S. (2014). Boundaries as junctures: collaborative boundary work for building efficient resilience. Journal of Public Administration Research and Theory 24(3), pp.673-695

René, B., \& Tharsi, T. (2004). Multi-party collaboration as social learning for interdependence: developing relational knowing for sustainable natural resource management. Journal of Community \& Applied Social Psychology, 14(3), pp.137-153.

Ring, P. S, and Van de Ven, A. H. (1994). Developmental processes of cooperative interorganizational relationships. Academy of Management Review, 19(1), pp.90-118.

Ritvala, T., Salmi, A., \& Andersson, P. (2014). MNCs and local cross-sector partnerships: The case of a smarter Baltic Sea. International Business Review, 23(5), pp.942-951

Rubin, I. S., \& Rubin, H. J. (1995). Qualitative interviewing: The art of hearing data. Thousand Oaks, CA

Ryan White comprehensive aids and resource emergency (CARE) Act (1990). Retrieved October 1, 2017,http://hab.hrsa.gov/livinghistory/timeline $\backslash 1990 . h t m l$

Sabatier, P. A., Focht, W., Lubell, M., Trachtenberg, Z., Vedlitz, A., \& Matlock, M. (2005). Swimming upstream: Collaborative approaches to watershed management. MIT press

Saldana, J., \& Omasta, M. (2017). Qualitative research: Analyzing life. SAGE Publications.

Salkind, N. (2009). Exploring research.7th eds. Upper Saddle River, NJ: Prentice Hall Saz-Carranza, A, \& Ospina, S. M. (2011). Behavioral dimensions of governing

interorganizational goal-directed networks - managing unity-diversity tension. Journal of Public Administration and Research Theory 21(2), pp.327-365.

Scott, T. A., \& Thomas, C. W. (2017). Unpacking the collaborative toolbox: Why and when do public managers 
choose collaborative governance strategies? Policy studies journal, 45(1), pp.191-214

Simo, G., \& Bies. A. L. (2007). The role of nonprofits in disaster response: an expanded model of cross-sector collaboration. Special issue, Public Administration Review 67(s1), pp.125-142.

Simo, G. (2009). Sustaining cross-sector collaborations: Lessons from New Orleans. Public Organization Review 9(4), p.367.

Sirianni, C. (2009). Investing in democracy: Engaging citizens in collaborative governance. Washington, DC: Brookings Institution Press

Sørensen, E., \& Torfing, J. (2011). Enhancing collaborative innovation in the public sector. Administration \& Society, 43(8), pp.842-868.

Stake, R. (1998). “Cases studies” (pp.86-109), in Denzin, N.K., Lincoln, Y.S.eds, Strategies of Qualitative Inquiry. Thousand Oaks, CA

Susskind, L, \& Cruikshank. J. (1987). Breaking the impasse: Consensual approaches to resolving public disputes. New York: Basic Books.

Thomson, A. M., \& Perry, J. L. (2006). Collaboration processes: Inside the black box. Public Administration Review, 66(s1), pp.20-32.

Thomas, R. M. (2003). Blending Qualitative and Quantitative Research Methods in Theses And Dissertations. Thousand Oaks, CA: Corwin Press

UNAIDS (2017). The global HIV/AIDS epidemic. Retrieved on October 4, 2017 from https://www.hiv.gov/hivbasics/overview/data-and-trends/global-statistics

Vangen, S., \& Huxham, C. (2003). Nurturing collaborative relations: Building trust in interorganizational collaboration. The Journal of Applied Behavioral Science, 39(1), pp.5-31

Vangen, S., and Huxham, C. (2012). The tangled web: unraveling the principle of common goals in collaborations. JPART 22, 22(4), pp.731-760.

Vangen, S. \& Winchester, N. (2013) 'Managing cultural diversity in collaborations', Public Management Review. 16(5), pp.686-707

Weber, E. P., and Khademian, A. M. (2008). Wicked problems, knowledge challenges, and collaborative capacity builders in network settings. Public Administration Review 68(2), pp.334-349

Yeager, K. A., \& Bauer-Wu, S. (2013). Cultural humility: Essential foundation for clinical researchers. Applied Nursing Research, 26(4), pp.251-256

Yin, R. K. (1984). "Introduction" (pp. 1-18), selection from conducting case studies (pp. 83-97) and "reporting case studies" (pp. 141-166). In: Case study research: Design and methods. 3rd ed.

Beverly Hills, CA: Sage.

Yin, R. K. (2003). Case study research: design and methods. Thousand Oaks, CA: Sage Publications

Zurba, M. (2014). Leveling the playing field: fostering collaborative governance towards on-going reconciliation. Environmental Policy and Governance, 24(2), pp.134-146

\section{First Author}

Dr. James Korku Agbodzakey is an Associate Professor of Public Leadership and the Director of the Urban SERCH Institute at UNT Dallas. He has extensive work experience in public, private, civic/nonprofit sectors in Africa, Caribbean, and the United States of America. His principal research focuses on HIV/AIDS care and treatment, particularly how the use of collaborative governance framework impacts categories of services to target populations. Dr. Agbodzakey served as a delegate for AIDS 2012 in Washington, D.C.; AIDS 2014 in Melbourne Australia; AIDS 2016 in Durban, South Africa; AIDS 2018 in Amsterdam, Netherlands, and recently as a delegate at the 10th IAS Conference on HIV Science in Mexico City, Mexico in 2019. Dr. Agbodzakey is committed to working with various stakeholders to help address contemporary complex urban challenges for citizens' benefits.

\section{Second Author}

Dr. Nicholas Bolden is an Assistant Professor of Public Administration and Policy at Columbus State University. His major teaching and research interest focus on state and local policy and public management, specifically in the areas of economic development, workforce development, and state and local government finance. Dr. Bolden has taught extensively in the field of public administration and provides training and policy consultant services to state and local agencies. Recently, Dr. Bolden served as a Work-Based Learning policy consultant to the Alabama Department of Commerce and The Office of the Governor, Kay Ivey. His recent publication he co-authored Do Political Parties Matter for the Funding Status of State Pension Plans appeared in the Journal of Regional and Policy Analysis. Nicholas Bolden received a Master of Public Administration from Troy University with a specialization in Adult Education and Training, and a Ph.D. in Public Administration and Policy from Auburn University. 


\section{Third Author}

Dr. Sandra Schrouder is an Associate Professor of Public Administration at Barry University in the School of Professional and Career Education (PACE). Dr. Schrouder has over 20 years teaching experience at both the graduate and undergraduate level and has taught in Jamaica, the Bahamas and the United States. Dr. Schrouder is committed to community development and engagement through her years of involvement in Parkland City Government Advisory Board, Broward Health Community Relations Board among other community organizations. Her research interests are in the areas of management, public policy analysis, public finance, education policies, organizational ethics, bureaucratic discretion, and juvenile justice. She frequently reviews articles for peer-reviewed academic journals as well as new and prospective textbooks in her field. She is the coauthor of Issues in the Development of Contemporary Caribbean Economies, along with Rupert Rhodd and Donna Cooke (2007). 